\title{
Implanting Melatonin at Lambing Enhances Lamb Growth and Maintains High Fat Content in Milk
}

José Alfonso Abecia ( $\square$ alf@unizar.es )

Universidad de Zaragoza Facultad de Veterinaria https://orcid.org/0000-0003-2827-3054

Silvia Luis

Universidad de Zaragoza Facultad de Veterinaria

Francisco Canto

Universidad de Zaragoza Facultad de Veterinaria

Research

Keywords: melatonin, milk, lambs, growth

Posted Date: March 26th, 2021

DOI: https://doi.org/10.21203/rs.3.rs-361387/v1

License: (c) (i) This work is licensed under a Creative Commons Attribution 4.0 International License.

Read Full License 


\section{Abstract}

Background: Recent studies have shown that melatonin implants administered during pregnancy reduced neonatal lamb mortality and produced high survival rates at weaning. This study was designed to quantify the effects of melatonin implantation of ewes and lambs immediately after lambing on the growth of lambs and the quality of milk throughout lactation.

Results: In experiment 1, treatment with melatonin the lambs did not have a significant effect on liveweight (LW) ( \pm S.E.M.) at weaning or average daily gain $(A D G)$ until weaning. These results were similar in experiment 2 , although lambs reared by melatonin-implanted ewes presented significantly $(P<0.05)$ higher $L W$ at weaning and ADG than did lambs from control ewes. The effect of melatonin implantation of the mothers was particularly evident in male lambs, so that male lambs reared by treated ewes presented significantly higher LW at week 2,3 , and 4 than did male lambs reared by control ewes. The fat content of milk was significantly $(P<0.05)$ higher in implanted ewes than it was in control ewes at day 45 of lactation. Protein and lactose content of milk did not differ significantly between groups. In experiment 3 , using artificially-reared lambs, melatonin treatment of the lambs at birth did not have a significant effect on LW at weaning, or ADG.

Conclusions: Melatonin treatment of ewes at lambing induced a high growth rate of their lambs and increased the fat content of the milk; however, the direct treatment with melatonin of the lambs at birth did not have an effect in their growth rate.

\section{Background}

Sexual seasonality, which is regulated by photoperiod, limits sheep productivity [1]. Melatonin is the hormone that transmits the photoperiodic information to the endocrine system, which dictates the precise timing of reproduction. Subcutaneous melatonin implants are a method for artificially controlling oestrus in sheep and, because melatonin is released at night, this procedure is used to cause a short daytime-like response without suppressing endogenous secretion [2-3]. In Mediterranean genotypes, melatonin implants increased significantly $(29 \%)$ the probability of pregnancy and fecundity (lambs born/ewe) $(0.25$ extra lambs/treated ewe) [4]. Recent studies have shown that, melatonin implants administered between $70 \mathrm{~d}$ and $120 \mathrm{~d}$ of pregnancy reduced neonatal mortality and high survival rates at weaning, which were mediated through an increase of survival of twins and an increase in tolerance for prolonged parturition in extensively managed sheep flocks [5-6]. Melatonin diffuses freely across the ovine placenta and blood-brain barrier [7-8], so maternal supplementation is readily able to deliver melatonin to the foetus before birth.

We have observed an improvement in colostrum quality if mothers receive implants at the fourth month of pregnancy [9], and lambs reared by implanted ewes were fed more IgG than were lambs from nonimplanted ewes. Furthermore, apparently, maternal melatonin in pregnancy plays an important role in the production of brown adipose tissue (BAT) and newborn thermoregulation because melatonin-deficient 
lambs were colder at birth and reacted abnormally to cold than did control lambs, and the effects of maternal melatonin deficiency were reduced in lambs whose mothers had been kept at a constant photoperiod in pregnancy [10]. Probably the improvement of colostrum quality from implanted ewes and the best thermoregulation of lambs born from melatonin-treated pregnant ewes were responsible for the lower mortality rates and higher growth rates that we documented in Merino lambs reared under extensive conditions in Australia [11].

This study was designed to quantify the effects of melatonin implantation of ewes and lambs immediately after lambing on the growth of lambs and the quality of milk throughout lactation.

\section{Methods}

\section{Experiment 1}

The experiment involved 53 Rasa Aragonesa lambs (29 singletons, 24 twins; 29 males, 24 females) born from 40 ewes in the first week of Nov. Lambs either did (group m; n=28; 15 males, 13 females) or did not (group c, $\mathrm{n}=25 ; 14$ males, 11 females) receive an 18-mg melatonin subcutaneous implant (Melovine, CEVA Salud Animal, Barcelona, Spain) at the base of the left ear $24 \mathrm{~h}$ after birth. A digital dynamometer recorded lamb weight at birth and weekly thereafter until weaning (7 weeks). Average daily gain (ADG) from birth to weaning was calculated.

\section{Experiment 2}

The experiment involved 55 Rasa Aragonesa lambs (2 singletons, 44 twins, 9 triplets; 31 males, 24 females) born from 31 ewes in the first fortnight of Oct. Twenty-four hours after lambing, ewes either did (group $\mathrm{M}, \mathrm{n}=15$ ) or did not (group $\mathrm{C}, \mathrm{n}=16$ ) receive an 18-mg melatonin subcutaneous implant (Melovine, CEVA Salud Animal, Barcelona, Spain) at the base of the left ear. At the same time, lambs either did (group $\mathrm{m}, \mathrm{n}=28 ; 16$ males, 12 females) or did not (group $\mathrm{c}, \mathrm{n}=27 ; 15$ males, 12 females) receive a melatonin implant. Thus, lambs were in one of four groups depending on their mother's and their own treatment groups ( $C c, n=15 ; C m ; n=13 ; M c, n=12 ; M m, n=15)$. Lambs were weighted at birth and weekly thereafter until weaning ( 6 weeks). Milk samples were collected at $15 \mathrm{~d}, 30 \mathrm{~d}$, and $45 \mathrm{~d}$ after lambing.

\section{Experiment 3}

The experiment involved 16 lambs (8 males, 8 females) born in the first week of Oct, which were separated from their mothers $24 \mathrm{~h}$ after birth after having been fed colostrum by their dams. Lambs either $\operatorname{did}(m, n=9)$ or did not $(c, n=7)$ receive an 18-mg melatonin subcutaneous implant (Melovine, CEVA Salud Animal, Barcelona, Spain) at the base of the left ear. They were moved to an artificial rearing unit, which was a $16-\mathrm{m}^{2}$ pen that had an electronic milk feeder (Delaval LKF1200). Milk was distributed through a pipeline system to individual nipples in the pen. Lambs were weighted at birth and weekly thereafter until weaning (5 weeks). 


\section{Milk analysis}

Milk samples from Experiment 2 were analysed by a milk analyser (Lactoscan SP+) that was calibrated for sheep following the manufacturer's instructions (Milkotronic Ltd., Bulgaria) for measuring fat, protein, lactose, solids not fat (SNF), total solids, and salt contents, and density, freezing point, $\mathrm{pH}$, and conductivity of the milk.

\section{Statistical methods}

Experiments 1 and 3 were based on a $2 \times 2$ factorial design in which the treatment with melatonin of lambs and the sex of the lambs were fixed effects. In experiment 2, a $2 \times 2 \times 2$ factorial design in which the treatment with melatonin of dams and lambs, and the sex of the lambs were fixed effects. The effects of the treatment on lamb growth, $A D G$, and milk quality (Experiment 2) were evaluated statistically using the GLM PROC (SPSS v. 26) in a model that included melatonin treatment of the lambs, melatonin treatment of their dams (Experiment 2), sex, and their interaction. In Experiment 2, paired-sample $t$ tests for each maternal group were used to detect significant differences in milk quality among days of milk sampling. Results are expressed as mean \pm SEM, and the level for statistical significance was set to $\mathrm{p}<0.05$.

\section{Results}

\section{Experiment 1}

Treatment with melatonin or sex of the lambs did not have a significant effect on LW $( \pm$ S.E.M.) at weaning (m: $14.41 \pm 0.42 ; \mathrm{c}: 14.9 \pm 0.57 \mathrm{~kg}$ ) (males: $14.86 \pm 0.44$; females: $14.4 \pm 0.60 \mathrm{~kg}$ ) or ADG until weaning (m: $221.35 \pm 7.80 ; \mathrm{c}: 234.96 \pm 10.60 \mathrm{~g} / \mathrm{d}$ ) (males: $230.24 \pm 8.35$; females: $225.10 \pm 10.64 \mathrm{~g} / \mathrm{d}$ ) (Fig. 1).

\section{Experiment 2}

Melatonin implants in lambs did not have a significant effect on LW at weaning ( $\mathrm{m}: 12.69 \pm 0.68 ; \mathrm{c}: 12.87$ $\pm 0.45 \mathrm{~kg}$ ) or ADG (m: $203.35 \pm 0.10 ; \mathrm{c}: 204.60 \pm 9.05 \mathrm{~g} / \mathrm{d}$ ) (Table 1); however, lambs reared by melatoninimplanted ewes presented significantly $(P<0.05)$ higher $L W$ at weaning $(M: 13.61 \pm 0.51 ; C: 12.09 \pm 0.57$ $\mathrm{kg})$ and $A D G(M: 221.00 \pm 10.45 ; 189.92 \pm 12.44 \mathrm{~g} / \mathrm{d})$ than did lambs from $\mathrm{C}$ ewes. Differences between groups in LW were significant from week 3 onwards (Fig. 2). The effect of melatonin implantation of the mothers was particularly evident in male lambs (Fig. 3); male lambs reared by treated ewes presented significantly higher LW at week 2,3 , and 4 than did male lambs reared by control ewes. 
Table 1

Live weight ( \pm S.E.M.) $(L W)$ at birth and weaning $(\mathrm{kg})$, and average daily gain (ADG) from birth to weaning $(\mathrm{kg} / \mathrm{d})$ of Rasa Aragonesa lambs whose mothers either did (M) or did not (C) receive an 18-mg melatonin subcutaneous implant (Melovine, CEVA Salud Animal, Barcelona, Spain) at the base of the left ear and, at the same time, the lambs either did $(m)$ or did not (c) receive a melatonin implants.

\begin{tabular}{|lllllll|}
\hline & Cc & Cm & Mc & Mm & \multicolumn{2}{c|}{ Treatment effect } \\
\hline $\mathrm{n}$ & 15 & 13 & 12 & 15 & lamb & mother \\
\hline LW Birth & $4.23 \pm 0.20$ & $3.93 \pm 0.13$ & $4.05 \pm 0.18$ & $4.23 \pm 0.11$ & ns & ns \\
\hline LW weaning & $12.52 \pm 0.56$ & $11.61 \pm 1.06$ & $13.40 \pm 0.75$ & $13.77 \pm 0.74$ & ns & * \\
\hline ADG & $0.197 \pm 0.01$ & $0.182 \pm 0.01$ & $0.216 \pm 0.01$ & $0.224 \pm 0.01$ & ns & * \\
\hline ns, non-significant; ${ }^{*} \mathrm{P}<0.05$ & & & & & \\
\hline
\end{tabular}

The fat content of milk was significantly $(P<0.05)$ higher in $M$ ewes than it was in $C$ ewes at day 45 of lactation, and decreased significantly $(P<0.05)$ throughout lactation in $C$ ewes, only (Fig. 4). Protein and lactose content of milk did not differ significantly between groups, although both increased significantly $(P<0.05)$ throughout lactation in the $C$ group. Those differences were apparent in SNF, density, and total solids $(P<0.05)$ in the $C$ group, only, and density in the $M$ group between day 30 and 45 . The percentage of total solids was higher $(P<0.05)$ in the $M$ group at day 45 of lactation (Fig. 4).

The treatment and control groups did not differ significantly in the $\mathrm{pH}$, conductivity, salt content, and freezing point of the milk, although the conductivity of samples collected on day 30 were significantly ( $P$ $<0.05)$ higher than were those collected on day 15 in both groups. The salt content of milk from $C$ ewes increased significantly $(P<0.05)$ throughout lactation, and milk from $M$ ewes increased significantly $(P<$ $0.05)$ from day 15 to day 30 . $C$ ewes presented a significant $(P<0.05)$ reduction in the freezing point of their samples from day 30 to day 45.

\section{Experiment 3}

Melatonin treatment did not have a significant effect on lamb birth weight ( $\mathrm{m}: 3.61 \pm 0.18$; $\mathrm{c} 3.79 \pm 0.28$ $\mathrm{kg}$ ), LW at weaning (m: $10.59 \pm 0.85 ; \mathrm{c}: 10.55 \pm 0.73 \mathrm{~kg}$ ), or ADG (m: $0.21 \pm 0.01 ; \mathrm{c}: 0.20 \pm 0.02 \mathrm{~kg} / \mathrm{d}$ ). The sexes differed significantly in ADG from birth to weaning, but not in LW at birth (males: $3.93 \pm 0.24$; females: $3.45 \pm 0.17 \mathrm{~kg}$ ) and at weaning (males: $11.37 \pm 0.66$; females: $9.78 \pm 0.87 \mathrm{~kg}$ ) did not. Females $(0.24 \pm 0.02 \mathrm{~kg} / \mathrm{d})$ had a higher growth rate than did males $(0.17 \pm 0.02 \mathrm{~kg} / \mathrm{d})(P<0.05)$.

\section{Discussion}

The main findings of the experiments were the effects of the melatonin treatment of dams at lambing on lamb weight and growth rate, in parallel with an increase in the fat content of the milk, especially at the 
end of lactation. Furthermore, the milk fat levels of treatment ewes persisted from the beginning to the end of lactation. To our knowledge, this is the first evidence of this effect in a small ruminant, particularly if exogenous melatonin is implanted at lambing. Previous studies on the effects of melatonin implants on milk production and/or offspring growth focused on implantation in the second half of pregnancy or in the middle of the milking period. It has been reported [12] that melatonin implants at day 35 of lactation did not have a significant effect on milk yield and composition in Manchega and Lacaune ewes, and a melatonin implant at mid-milking did not have a significant effect on milk yield throughout the milking period in Lacaune and Assaf dairy ewes [13]. Cashmere goats that had received an implant at day 50 of lactation presented a higher fat content in the milk of than was in the milk of control goats; however, daily yields of milk, milk protein, and milk lactose were lower in the implanted goats than they were in the controls goats [14]. Melatonin administration to does in the dry period, seven weeks before kidding, produced a galactopoietic response in the subsequent lactation and an improved daily weight gain of their suckling kids, especially, males [15].

In our experiments, lambs that were reared by implanted ewes had a higher growth rate than did the lambs from control ewes, which might have been due to a higher volume of milk from their implanted dams (not measured), and or the higher fat content of milk, especially at the end of lactation. A high milk fat concentration, milk energy content, and milk energy concentration contributes to faster lamb growth. The administration of exogenous melatonin coupled with the simulation of a short-day photoperiod in summer had significant effects on the milk levels of solids, protein, fat, and lactose, and on the fatty acid content of sheep milk [16]. Furthermore, the higher content of total solids in the milk of M Rasa Aragonesa ewes might have contributed to the higher growth rates of the lambs because total solids are a combination of fat, protein, lactose, and minerals. In one study, a $30 \%$ reduction in overall milk solids was correlated with a $20 \%$ reduction in total milk energy production [17].

Although milk yield was not measured in our experiment, the significant increase in protein and lactose in the control group of ewes throughout lactation, which did not occur in the $\mathrm{M}$ group, might indicate lower milk production in the $\mathrm{C}$ group because of a dilution effect [18]. This dilution factor was cited [19] as an explanation for the correlation between low levels of protein and lactose in milk and high milk production in sheep.

The three experiments did not indicate any direct effect of implanting melatonin in the lambs whether they were reared by their dams or artificially. Evidence of treatment with melatonin in suckling lambs is limited. Implanting lambs with a single melatonin sachet subcutaneously on the back at 3-4 weeks of age [20] did not affect growth rate, and a pinealectomy of prepubertal sheep did not affect growth rate [21]. The administration of melatonin by intravenous infusion or through transdermal patches to newborn lambs that had been subject to induced asphyxia, reduced the pathologies caused by asphyxia [22]. In newborn lambs, treatment with melatonin reduced the in vivo pulmonary pressor response to changes in oxygenation [23] or presented an antiproliferative effect against pathologies such as pulmonary arterial hypertension in neonates [24]. Melatonin given to human newborns with sepsis reduced the number that died because of its highly effective antioxidant and free-radical scavenging properties [25]. Although 
melatonin treatment has positive effects on the newborn's health, no evidence of an effect on growth rates has been presented. Melatonin treatment of ewes in mid- or late pregnancy has positive effects on lambs. It has been reported [6] that maternal melatonin supplementation in the second half of pregnancy improved the survival of second-born twin lambs, so that melatonin implants have potential as a simple and cost-effective strategy to reduce neonatal losses of twin lambs on farm. Our group has demonstrated an improvement in colostrum quality if ewes are implanted at the fourth month of pregnancy [9], and higher survival and growth rates from birth to weaning of Merino lambs [11]. Probably, the increased survival is mediated by the high colostrum quality, and by an increase in BAT and birth weight if maternal melatonin implants were inserted from day 100 of gestation [26].

Our experiments indicated no significant differences in the growth rates of male and female lambs, and even among artificially reared lambs, females had higher growth rates than did males. It has been observed that ewe lambs at the end of milk rearing had a higher average daily gain than did ram lambs, probably, because of differences in the feeding behaviour of males and females fed ad libitum [27]; specifically, females tend to consume less milk per meal than do males, but consume more meals per day than do males [28].

The higher growth rate of lambs reared by implanted dams might have been mediated by a higher melatonin concentration in their mother's milk, which in turn might have affected the lamb's health. In cows and goats, milk melatonin levels reflect blood concentrations of melatonin, with a short delay [29], and it was speculated [30] that melatonin that is supplied to the infant via breast milk plays a role in improving sleep and reducing colic in breast-fed human offspring. The lamb can readily produce an appropriately timed melatonin rhythm by $1-6$ weeks of age [31] and, although maternal melatonin is predominant before birth, significant but low-amplitude increases in nighttime melatonin can occur within the first week [32]. In any case, the absence of differences between $c$ and $m$ lambs from the $M$ group of ewes in Experiment 2, and the results from Experiment 3, in which lambs did not receive milk from their mothers, did not receive extra melatonin from milk, lead us to conclude that neither exogenous or endogenous melatonin of the lambs, or melatonin from their mothers' milk have a direct effect on growth rate.

\section{Conclusions}

In conclusion, treatment ewes with melatonin at lambing induced a high growth rate in their lambs and produced an increase in the fat content of the milk; however, the direct treatment with melatonin of the lambs at birth did not have a significant effect on their growth rate.

\section{Declarations}

Acknowledgements 
We thank Bruce MacWhirter for the English edition of the manuscript and José Antonio Ruiz and Antonio Barrio for their help in the care of the animals.

\section{Authors' contributions}

Conceptualization, J.A.A. and S.L.; methodology, J.A.A., S.L. and F.C..; investigation, J.A.A. and S.L.; resources, J.A.A.; data curation, S.L.; writing-original draft preparation, J.A.A.; writing-review and editing, J.A.A., S.L. and F.C..; project administration, J.A.A.; funding acquisition, J.A.A. All authors have read and agreed to the published version of the manuscript.

\section{Funding}

Partially funded by Gobierno de Aragon (Group BIOFITER).

\section{Ethics approval and consent to participate}

The experiment was conducted at the experimental farm of the University of Zaragoza, Spain ( $\left.41^{\circ} 40^{\prime} \mathrm{N}\right)$, under procedures approved by the Ethics Committee for Animal Experiments at the University of Zaragoza, and in accordance with the Spanish Policy for Animal Protection RD1201/05, which meets the European Union Directive 2010/63 on the protection of animals used for experimental and other scientific purposes.

\section{Consent for publication}

The authors declare consent for publication.

\section{Competing interests}

The authors declare no competing interests

\section{Availability of data and materials}

The datasets during and/or analysed during the current study available from the corresponding author on reasonable request.

\section{References}

1. Yeates NTM. The breeding season of the ewe with particular reference to its modification by artificial light. J Agric Sci Cambr. 1949;39:1-43.

2. O'Callaghan D, Karsch FJ, Boland MP, Roche FJ. Role of short days in timing the onset and duration of reproductive activity in ewes under artificial photoperiods. Biol Reprod. 1991;44:23-28.

3. Malpaux B, Viguié C, Skinner DC, Thiéry JC, Chemineau P. Control of the circannual rhythm of reproduction by melatonin in the ewe. Brain Res Bull. 1997;44:431-438. 
4. Palacín I, Forcada F, Abecia JA. Meta-analysis of the efficacy of melatonin implants for improving reproductive performance in sheep. Span J Agric Res. 2011;9:730-743.

5. Flinn T, Gunn JR, Kind KL, Swinbourne AM, Weaver AC, Kelly JM, et al. Maternal melatonin implants improve twin Merino lamb survival. J Anim Sci. 2020;98:skaa344.

6. Flinn T, McCarthy NL, Swinbourne AM, Gatford KL, Weaver AC, McGrice HA, et al. Supplementing Merino ewes with melatonin during the last half of pregnancy improves tolerance of prolonged parturition and survival of second-born twin lambs. J Anim Sci. 2020;98:skaa372.

7. Yellon SM, Longo LD. Melatonin rhythms in fetal and maternal circulation during pregnancy in sheep. Am J Physiol Endocrinol Metab. 1987;252:E799-802.

8. Aly H, Elmahdy H, El-Dib M, Rowisha M, Awny M, El-Gohary T, et al. Melatonin use for neuroprotection in perinatal asphyxia: a randomized controlled pilot study. J Perinatol. 2015;35:186-191.

9. Abecia JA, Garrido C, Gave M, García, Al, López D, Luis S, et al. Exogenous melatonin and male foetuses improve the quality of sheep colostrum. J Anim Physiol Anim Nutr. 2020;104:1305- 1309.

10. Seron-Ferre M, Reynolds H, Mendez NA, Mondaca M, Valenzuela F, Ebensperger R, et al. Impact of maternal melatonin suppression on amount and functionality of brown adipose tissue (BAT) in the newborn sheep. Front Endocrinol 2015;5:232.

11. Davis R, Green JM, Abecia JA. Field trials of the use of melatonin implants during pregnancy as a tool to improve lamb performances. Proc British Soc Anim Sci (BSAS) 2021 Conf, 12-15 April 2021.

12. El Hadi $A$. The impact of shearing and hormonal treatments (melatonin or cabergoline) in lactating dairy ewes. PhD Thesis, 2020. Universidad Autonoma de Barcelona, Spain.

13. Abecia JA, Forcada F, Valares JA, Palacín I, Martín S, Martino A, et al. Does melatonin treatment during lactation influence milk production in Lacaune and Assaf ewes?. Span J Agric Res. 2005;3:396-401.

14. Yang $\mathrm{CH}, \mathrm{Xu} \mathrm{JH}$, Ren QC, Duan T, Mo F, Zhang W. Melatonin promotes secondary hair follicle development of early postnatal cashmere goat and improves cashmere quantity and quality by enhancing antioxidant capacity and suppressing apoptosis. J Pineal Res. 2019;67:e12569.

15. Avilés R, Delgadillo JA, Flores JA, Duarte G, Vielma J, Flores MJ, et al. Melatonin administration during the dry period stimulates subsequent milk yield and weight gain of offspring in subtropical does kidding in summer. J Dairy Sci.2019;102:11536-11543.

16. Molik E, Bonczar G, Żebrowska A, Misztal T, Pustkowiak H, Zięba D. Effect of day length and exogenous melatonin on chemical composition of sheep milk. Arch Anim Breed. 2011;54:177-187.

17. Muir Pd, Smith NB, Wallace GJ, Fugle CJ and Bown MD. Maximising lamb growth rates. Proc NZ Grassland Assoc 2000;62:55-58.

18. Othmane MH, Carriedo JA, de la Fuente LF, Primitivio FS Factors affecting test-day milk composition in dairy ewes, and relationships amongst various milk components. J Dairy Res. 2002;69:53-62.

19. Bianchi AE, Macedo VP, Schafer Da Silva A, Finkler da Silveira AL. Effect of the addition of protected fat from palm oil to the diet of dairy sheep. Rev Bras de Zootec. 2018;47:e20160137. 
20. Kennaway DJ, Gilmore TA. Effects of melatonin implants in ewe lambs. J Reprod Fertil 1984;70:3945.

21. Brown WB, Forbes JM. Diurnal variations of plasma prolactin in growing sheep under two lighting régimes and the effect of pinealectomy. J Endocrinol. 1980;84:91-99.

22. Aridas JDS, Yawno T, Sutherland AE, Nitsos I, Ditchfield M, Wong FY, et al. Systemic and transdermal melatonin administration prevents neuropathology in response to perinatal asphyxia in newborn lambs. J Pineal Res. 2018;64:e12479.

23. Astorga CR, González-Candia A, Candia AA, Figueroa EG, Cañas D, Ebensperger G, et al. Melatonin decreases pulmonary vascular remodeling and oxygen sensitivity in pulmonary hypertensive newborn lambs. Front Physiol 2018;9:185.

24. Rivera E, García-Herrera C, González-Candia A, Celentano DJ, Herrera EA. Effects of melatonin on the passive mechanical response of arteries in chronic hypoxic newborn lambs. J Mech Behav Biomed Mater. 2020;112:104013.

25. Gitto E, Karbownik M, Reiter R, Tan DX, Cuzzocrea S, Chiurazzi P, et al. Effects of melatonin treatment in septic newborns. Pediatr Res. 2001;50:756-760.

26. Sales F, Parraguez VH, McCoard S, Cofré E, Peralta OA, Subiabre I. Fetal brown fat deposition is increased by melatonin implants in sheep. J Anim Sci. 2017;95:152-153.

27. Makovický P, Gálisová Čopíková M, Margetín M, Makovický P, Nagy M Growth intensity of lambs during artificial milk rearing depending on chosen non genetic factors. Iranian Journal of Applied Animal Science 2019;9:257-263.

28. David I, Bouvier F, Ricard E, Ruesche J, Weisbecker J. Feeding behaviour of artificially reared Romane lambs. Animal 2014;86:982-990.

29. Eriksson L, Valtonen M, Laitinen JT, Paananen M, Kaikkonen M. Diurnal rhythm of melatonin in bovine milk: pharmacokinetics of exogenous melatonin in lactating cows and goats. Acta Vet Scand. 1998;39:301-310.

30. Cohen Engler A, Hadash A, Shehadeh N, Pillar G. Breastfeeding may improve nocturnal sleep and reduce infantile colic: Potential role of breast milk melatonin. Eur J Pediatr. 2012;171:729-732.

31. Claypool, LE, Wood RI, Yellon SM, Foster DL. The ontogeny of melatonin secretion in the lamb. Endocrinol. 1989;124:2135-2143.

32. Foster DL, Ebling FJP, Claypool LE, Wood RI, Adel TE, Schramm w. Amplitude modulation of the nightly melatonin rise in the neonatal lamb and the subsequent timing of puberty. Biol Reprod. 1989;40:920-928.

\section{Figures}



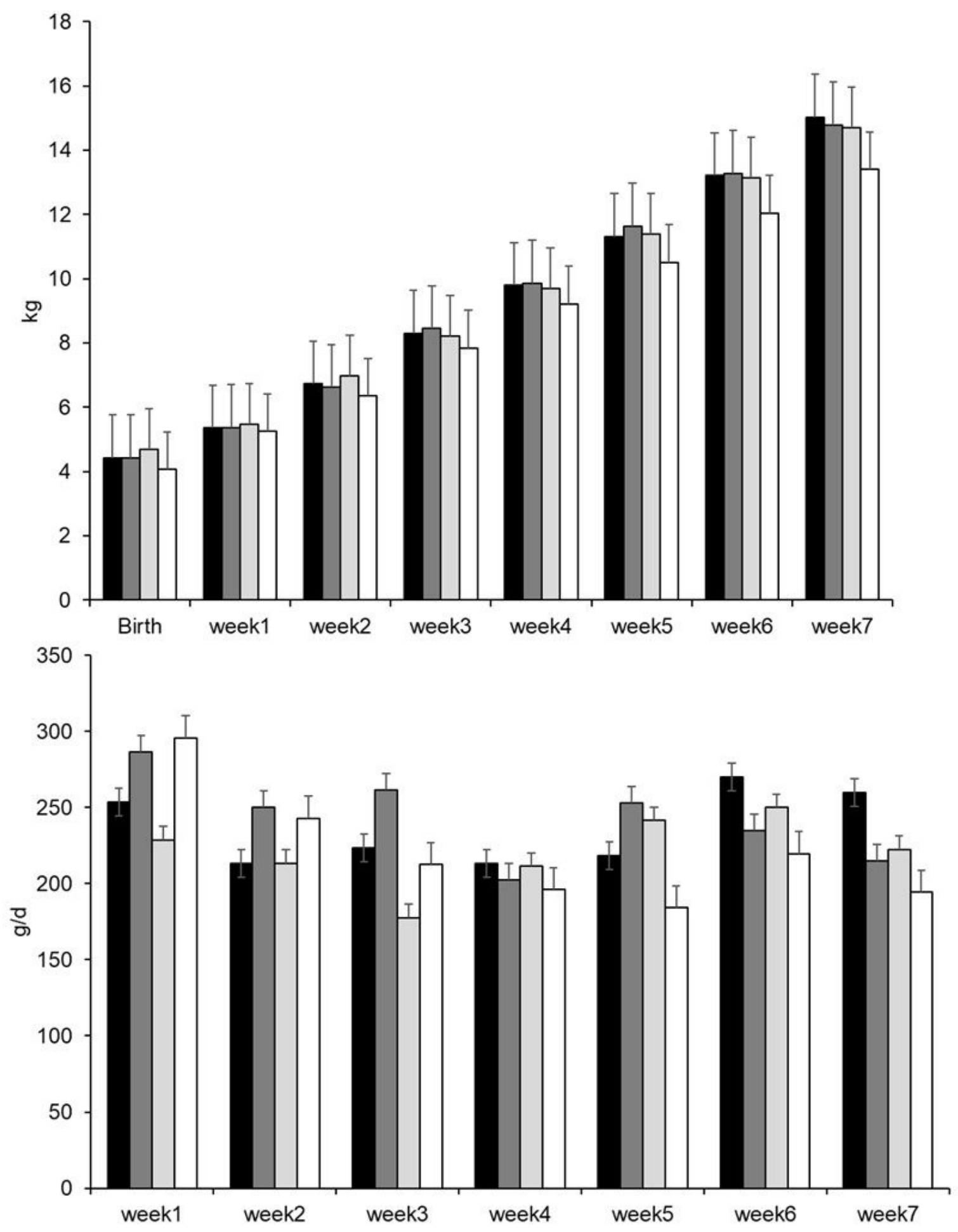

-control males amelatonin males $\square$ control females $\square$ melatonin females

\section{Figure 1}

Mean ( \pm S.E.M.) weekly live weight and average daily gain $(\mathrm{g} / \mathrm{d})$ of Rasa Aragonesa lambs that either did ( $n=28 ; 15$ males-13 females) or did not ( $n=25 ; 14$ males-11 females) receive an 18-mg melatonin subcutaneous implant (Melovine, CEVA Salud Animal, Barcelona, Spain) at the base of the left ear $24 \mathrm{~h}$ after birth. 


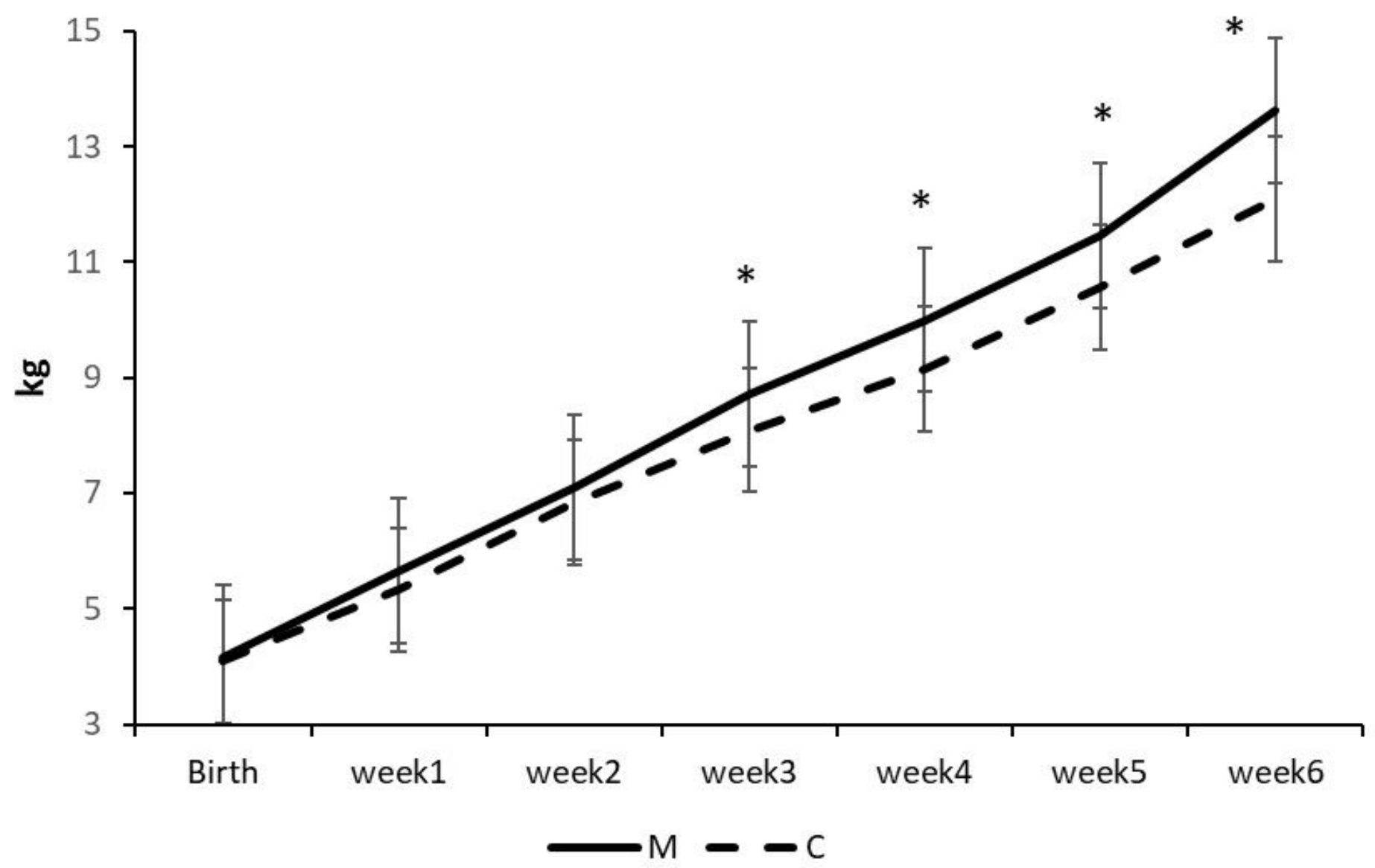

Figure 2

Mean ( \pm S.E.M.) weekly live weight of Rasa Aragonesa lambs whose mothers either did (M) or did not (C) receive an 18-mg melatonin subcutaneous implant (Melovine, CEVA Salud Animal, Barcelona, Spain) at the base of the left ear $24 \mathrm{~h}$ after lambing. 


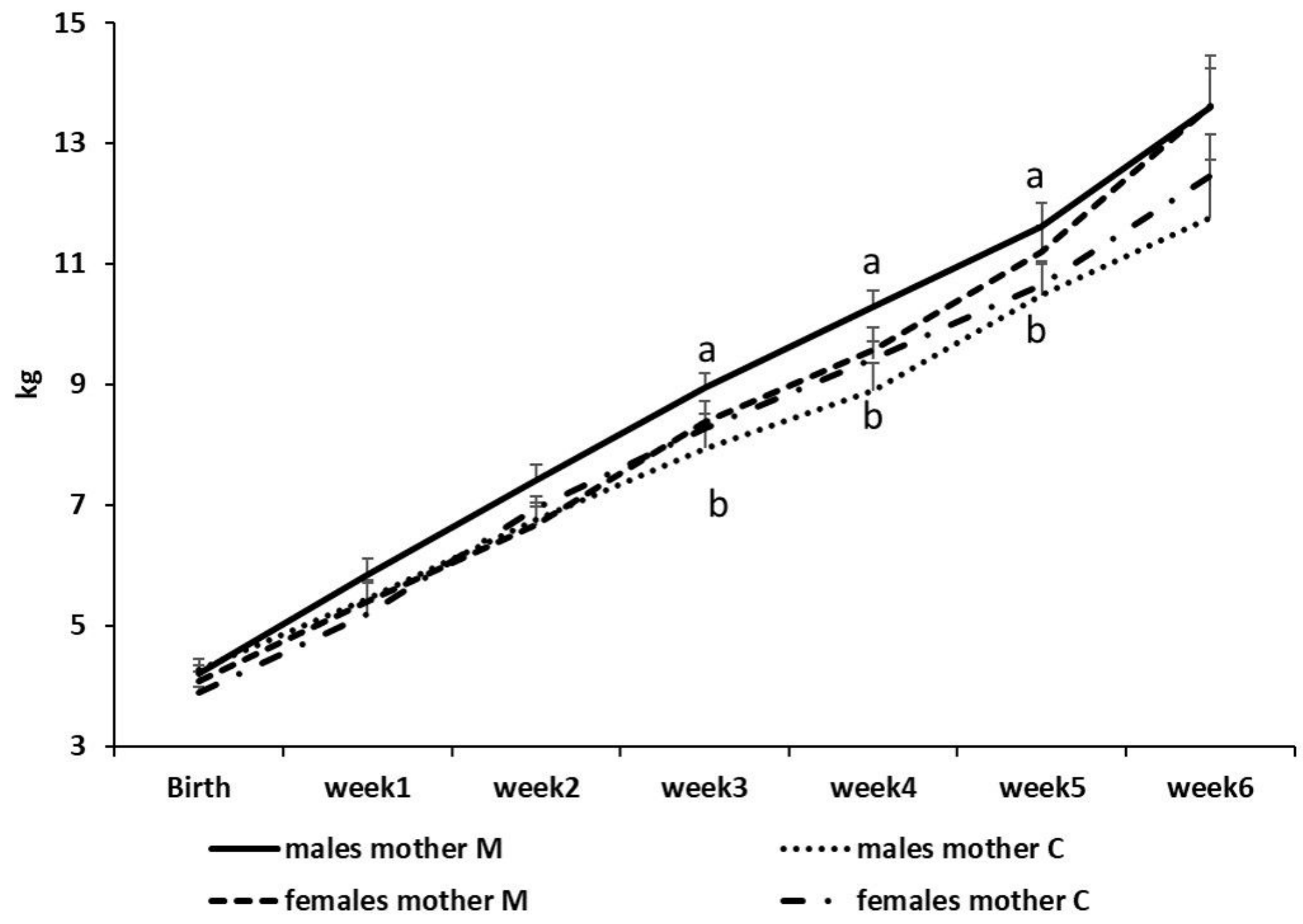

Figure 3

Mean ( \pm S.E.M.) weekly live weight of male and female Rasa Aragonesa lambs whose mothers either did (M) or did not (C) receive an 18-mg melatonin subcutaneous implant (Melovine, CEVA Salud Animal, Barcelona, Spain) at the base of the left ear $24 \mathrm{~h}$ after lambing (letters indicate significant differences at $\mathrm{P}<0.05)$. 

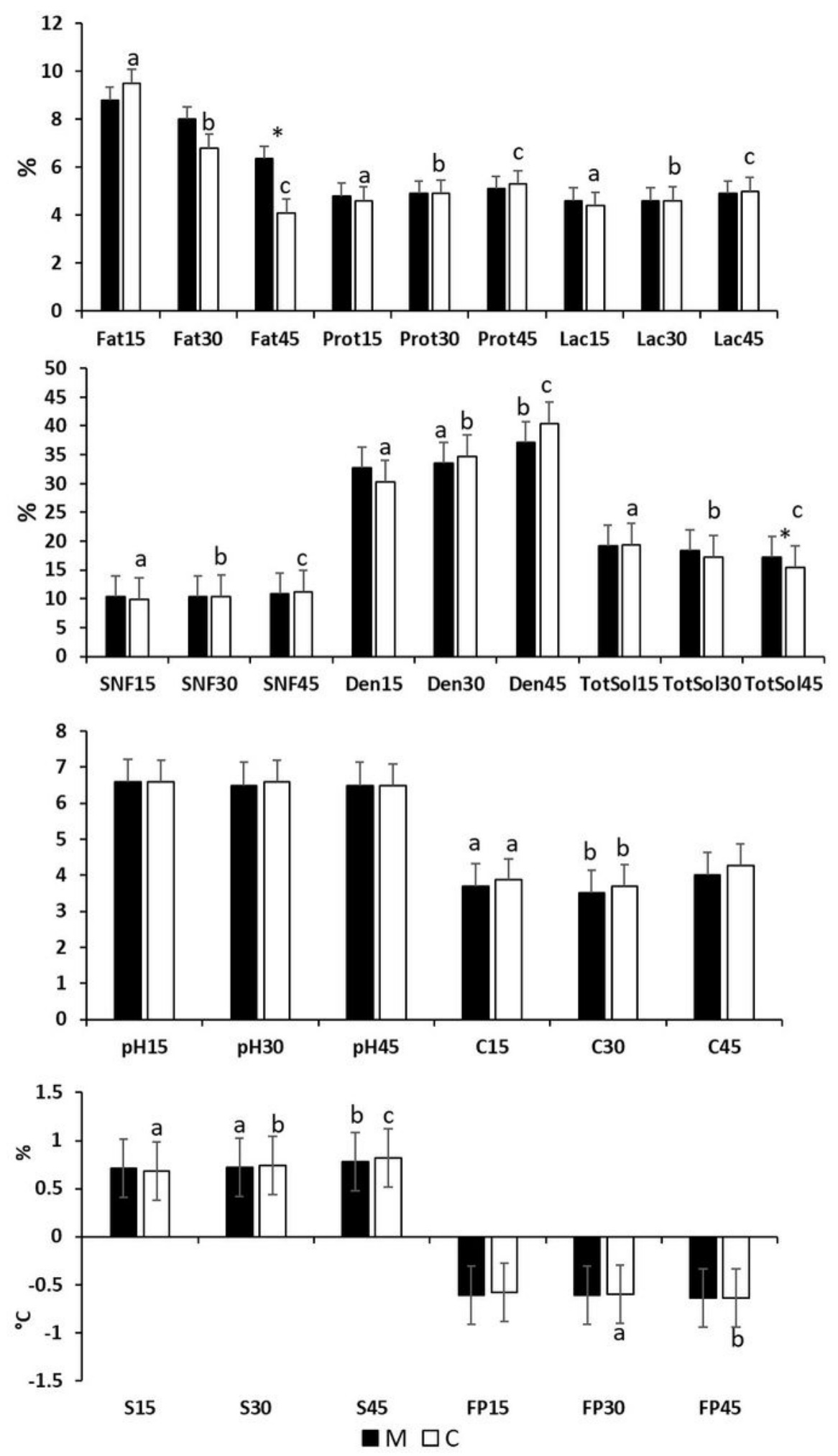

Figure 4

Mean ( \pm S.E.M.) fat, protein (Prot), lactose (Lac), solids not fat (SNF) percentages, and density (Den), total solids (TotSol), $\mathrm{pH}$, conductivity (C), salt content (S), and freezing point $\left({ }^{\circ} \mathrm{C}\right)$ of milk samples collected at days 15, 30, and 45 of lactation from Rasa Aragonesa ewes that either did (M) or did not (C) receive an 18-mg melatonin subcutaneous implant (Melovine, CEVA Salud Animal, Barcelona, Spain) at the base of 
the left ear $24 \mathrm{~h}$ after lambing (letters indicates significant differences at $\mathrm{P}<0.05$ among days; * indicates significant differences between groups at $\mathrm{P}<0.05$ ). 